M.C. ХMIЛЬ

\title{
ПРЕГРАВІДАРНА ПІДГОТОВКА ПАЦІЄНТОК ІЗ СИНДРОМОМ ПОЛІКІСТОЗНИХ ЯЄЧНИКІВ У ПРОГРАМАХ ЕКСТРАКОРПОРАЛЬНОГО ЗАПЛІДНЕННЯ
}

\author{
ДВН3 «Тернопільський державний медичний університет \\ імені І.Я. Горбачевського МОЗ України», м. Тернопіль, Україна
}

\begin{abstract}
Мета: оцінити ефективність прегравідарної терапії перед проведенням контрольованої стимуляції овуляції в протоколах екстракорпорального запліднення у пацієнток із синдромом полікістозних яєчників.

Матеріали і методи. Рандомізоване клініко-лабораторне дослідження було проведено серед 146 жінок із верифрікованим синдромом полікістозних яєчників. При дослідженні використано загальноклінічні, ембріологічні та гормональні методи обстеження, ультразвукове дослідження.

Результати. На основі проведених власних досліджень встановлено, що у пацієнток, яким застосовували комплексну прегравідарну підготовку в програмах допоміжних репродуктивних технологій, спостерігали істотно вищі показники якості яйцеклітин, частоти дроблення ембріонів та вищий відсоток отриманих бластоцист, також доведено, що використання кріопротоколів підвищує частоту настання вагітності.

Висновки. Прегравідарна підготовка перед протоколом контрольованої стимуляції овуляції у пацієнток із безпліддям при синдромі полікістозних яєчників покращує якість яйцеклітин, збільшує частоту настання вагітності, знижує прояви метаболічного синдрому.
\end{abstract}

КЛЮЧОВІ СЛОВА: синдром полікістозних яєчників; безпліддя; контрольована стимуляція овуляції; якість яйцеклітин; FT 500 Plus; інозитол, вітамін $\mathrm{D}_{3}$.

Безпліддя на сьогодні є однією із актуальних проблем в акушерстві та гінекології, і має не тільки медичне значення, але й соціально-економічне, оскільки впливає на демографрічну ситуацію в нашій країні. Одним із фракторів, що призводить до безпліддя, $€$ синдром полікістозних яєчників (СПкЯ), частота якого у жінок репродуктивного віку становить 6-20\%. Серед пацієнток 3 ендокринним безпліддям синдром полікістозних яєчників спостерігають в 40-50 \%. За даними літератури, СПКЯ діагностують майже у 50 \% жінок із порушеннями менструальної та овуляторної фрункцій. Відзначено, що понад 100 млн жінок віком від 15 до 49 років мають СПКЯ [1, 4, 5, 20].

На початку третього тисячоліття прийшло нове осмислення СПКЯ як глобальної проблеми соматичного здоров'я - ендокринно-метаболічного статусу, серцево-судинного та онкологічного ризику. Більш того, без попередньої корекції гормональних порушень реакція яєчників у хворих із СПКЯ і безпліддям ендокринного генезу на стимуляцію знижена [14].

Велику увагу науковців привертає пошук нових методів лікування СПКЯ, які дозволять досить швидко і ефективно нормалізувати гормональні порушення, розміри і структуру яєчників [10, 12].

Тимчасовий ефект дають усі методи лікування, які спрямовані лише на відновлення

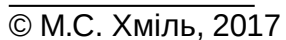

репродуктивної фрункції. Для відновлення фрертильності сьогодні використовують медикаментозні препарати, які забезпечують фролікулогенез в яєчниках з утворенням одного або декількох зрілих фролікулів і запускають овуляцію. Прегравідарна підготовка дозволяє виявити фрактори ризику репродуктивних втрат та забезпечити їх ліквідацію до початку лікування безпліддя [11].

Вельми актуальним питанням на сьогодні залишається роль дефіциту вітаміну D в патогенезі СПкЯ. При достатній його кількості в організмі визначають позитивний ефект на результати запліднення при застосуванні допоміжних репродуктивних технологій (ДРТ) та на регуляцію функцій репродуктивної системи жінки в цілому $[7,21]$. Рецептори вітаміну D містяться в тканинах яєчника та ендометрії. Похідні вітаміну D модулюють синтез естрадіолу, прогестерону та антимюллерового гормону. Його застосування підвищує чутливість тканин до інсуліну, забезпечує зниження маси тіла пацієнтки, нормалізує та підтримує порушений мінеральний обмін [2, 6, 13, 18, 23].

Комбінована терапія при СПКЯ додатково включає інозитол та його похідні, які є одними 3 найактивніших вторинних посередників, що беруть участь у каскаді біохімічних процесів, а саме у внутрішньоклітинній передачі сигналу, та необхідні для фрункціонування рецепторів статевих гормонів, оракторів росту, інсуліну, катехоламінів та ін. 
Інозитол задіяний в нормалізації та підтриманні фрізіологічного жирового обміну, знижує рівень тестостерону, а також бере участь у функціонуванні репродуктивної системи, нормалізації та відновленні овуляції, активації яйцеклітин і розвитку ембріона до стадії бластоцисти, інвазії трофобласта [3, 16].

Мета дослідження: оцінити ефрективність прегравідарної терапії перед проведенням контрольованої стимуляції овуляції в протоколах екстракорпорального запліднення (ЕКЗ) у пацієнток із СПКЯ.

Матеріали і методи. Рандомізоване клініколабораторне дослідження було проведено серед 146 жінок із верифрікованим діагнозом СПкя та такими характеристиками: вік $(29,8 \pm 3,2)$ року (від

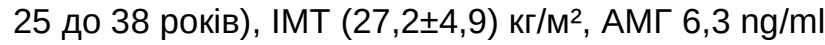
(4,1-11,6 ng/ml). Тривалість безпліддя була від 2 до 19 років, у середньому $(6,8 \pm 0,5)$ року. Первинне безпліддя було у 102 пацієнток (69,9 \%), а вторинне - у 44 жінок (30,1\%). Середній вік жінок, у якому починалось менархе складав $(14,1 \pm 0,3)$ року, у всіх жінок цикл був нерегулярним, у 118 жінок (80,8 \%) менструальний цикл тривав від 30 до 150 днів.

Обстеження та лікування здійснювали відповідно до наказу Міністерства охорони здоров'я України від 09.09.2013 р. № 787 «Про затвердження Порядку застосування допоміжних репродуктивних технологій в Україні» [8] та наказу Міністерства охорони здоров'я України від 29.11.2013 р. № 1030/102 «Про удосконалення системи планування сім'ї та охорони репродуктивного здоров'я в Україні» [9].

У подружніх пар перед програмою ДРТ було проведено збір даних щодо попереднього обстеження та лікування з наступним обов'язковим стандартним протоколом обстеження (ОСПО). Для пацієнток необхідними були: висновок терапевта про стан соматичного здоров'я та відсутність протипоказань для виношування вагітності, визначення групи крові та резус-срактора, клінічний аналіз крові, коагулограма, аналізи крові на сифіліс, ВІЛ, гепатити В і C, аналізи крові (IgM, IgG) на токсоплазмоз, хламідії, цитомегаловірус та корову краснуху, бактеріоскопічний аналіз виділень із трьох точок (вагіни, уретри і цервікального каналу), цитологічне дослідження мазків із шийки матки, загальне гінекологічне обстеження, ультразвукове дослідження органів малого таза, аналіз крові на антимюллерів гормон (АМГ), пролактин (Прл), фолітропін (ФСГ), лютропін (ЛГ), прогестерон (П), естрадіол (Е2). За показаннями пацієнток консультували лікарі-генетики, мамологи, ендокринологи, а також проводили дослідження на наявність антиспермальних та антифосороліпідних антитіл, каріотипування. При необхідності використовували інвазивні лікувально-діагностичні заходи: гістероскопія, гістеросальпінгографія та ін.
Результати дослідження та їх обговорення. Відповідно до поставленої мети та завдань дослідження пацієнтки були поділені на 2 групи. Першу групу склали 76 пацієнток із безпліддям при СПкЯ, які перед проведенням контрольованої стимуляції овуляції отримували комбіновану терапію вітамінного комплексу «FT 500 Plus» (інозитол 2000 мг (вітамін $B_{8}$ ), вітамін C 160 мг, вітамін Е 12 мг, фролієва кислота 400 мкг, селен 55 мкг, глутатіон 50 мг, цинк 10 мг, лютеїн 3 мг) 1 пакетик 1 раз на добу впродовж 2-3 місяців, та препарат вітаміну $D_{3}$ «Аквадетрим» у середньотерапевтичних дозах по 2 краплі 2-3 рази на добу, залежно від концентрації $25(\mathrm{OH})$ D у сироватці крові протягом 2-3 місяців.

Другу групу склали 70 пацієнток із безпліддям при СПКЯ, котрі щодня протягом 2-3 місяців перед стимуляцією овуляції, та в протоколі контрольованої овуляторної стимуляції до пункції фролікулів приймали фролієву кислоту (400 мкг).

В обох групах контрольовану стимуляцію овуляції проводили з використанням рекомбінантного гонадотропіну коріфолітропіну-альфра - «ЕЛОНВА». Препарат має пролонговану дію за рахунок модифікації карбоксикінцевого пептиду субодиниці бета-ланцюга людського ФСГ. На 5-7 день протоколу залежно від реакції яєчників, коли розмір фолікула досягав 14-15 мм призначали щоденно антагоніст гонадотропін-рилізинг гормон (ГнРГ) «Оргалутран» по 0,25 мг. На 8 день від введення «ЕЛОНВА» продовжили стимуляцію рекомбінантним ФСГ «Пурегон» до кінцевого дозрівання ооцитів (3 фолікули >17 мм), в якості тригера використовували агоніст рилізинг гормон «Диферелін».

Через 36 годин від введення тригера овуляції проводили забір ооцитів. Запліднення яйцеклітин та культивування ембріонів із подальшою вітрифікацією на 5-6 добу (стадія бластоцисти) здійснювали в умовах ембріологічної лабораторії. Оцінку ооцитів проводили після денудації, перед процедурою ICSI. Оцінювали мейотичний стан ооцитів (GV, MI, MII), тільки ооцити на стадії профрази I другого мейотичного поділу (MII) придатні для запліднення методом ICSI. У циклах IVF/ICSI характеристику здійснювали за морфологічними параметрами: оцінка прозорої оболонки (zona pellucida), зміни у величині та фрормі самого ооцита, якість, характеристика перивітелінового простору, стан полярного тіла $[17,22]$. Результати запліднення оцінювали через 16-19 годин після процедури ICSI, показники дроблення та вихід бластоцист на 3 та 5-6 добу. Якісну характеристику ембріонів на стадії бластоцисти проводили за системою Gardner [15].

Перенесення ембріонів здійснювали в кріоциклах у зв'язку з високою імовірністю розвитку синдрому гіперстимуляції яєчників (СГЯ). Після перенесення ембріонів у порожнину матки, 
пацієнтки отримували підтримувальну терапію до отримання результату на $\beta$-ХГЛ. При позитивному результаті на вагітність підтримку продовжували до 10-12 тижнів.

Основним методом лікування безпліддя у хворих із СПкЯ є допоміжні репродуктивні технології, мета яких - настання вагітності у конкретному циклі стимуляції овуляції. Всі ці пацієнтки належать до групи ризику розвитку синдрому гіперстимуляції яєчників - ускладнення, що найчастіше зустрічається в протоколах КОС. Тому його профрілактика $\epsilon$ одним із ключових питань програм допоміжних репродуктивних технологій. Використання коротких протоколів 3 антагоністами ГнРГ та тригером агоністом ГнРГ дає можливість уникнути синдрому гіперстимуляції. В обстежуваних нами 146 жінок із синдромом полікістозних яєчників було виявлено легку ступінь СГЯ у 5 жінок, що склало 3,4%. Враховуючи великий фрактор ризику, проводили вітрифрікацію ембріонів та ембріотрансфер у кріоциклі, що підвищило шанси настання вагітності. Відомо, що якість яйцеклітин у пацієнток із СПКя при використанні тригера овуляції агоніста ГнРГ, порівняно 3 хоріонічним гонадотропіном, є суттєво нижчою, також знижується відсоток запліднення, дроблення, кількості бластоцист та, відповідно, настання вагітності [19].

Проводили оцінку ефективності якості лікування за такими показниками: коефіцієнт пунктованих фолікулів без промивання до числа отриманих ооцитів; сумарний коефіцієнт ефективності отриманих ооцитів, ступінь зрілості ооцитів, частота запліднення, дроблення ембріонів, вихід бластоцист та відсоток настання вагітності. Коефріцієнт пунктованих фролікулів без промивання до числа отриманих ооцитів в 1 групі 0,79\%, а в 2 - 0,73 \%.
Сумарний коефріцієнт ефективності отримання ооцитів, включно ооцити після промивання фролікулів, у 1 групі - 0,82 \%, а в 2 групі - 0,77\%. Частка незрілих ооцитів у групі становила $16 \%$, в 2 - $20 \%$. Частота запліднення у 1 групі - 81,4\% у 2 - 78,1 \%; частота дроблення ембріонів у 1 групі $-75,4 \%$, а в 2 - 71,2 \%, вихід бластоцист у 1 групі - 41,3 \% а в 2 - 40,4 \%. Частота клінічних вагітностей в 1 групі була 44,1\%, відсоток викиднів - 16,8 \%; у 2 групі, відповідно, 43,3 \% і 17,5\%. У всіх пацієнтів було перенесено 1-2 ембріони, в середньому 1,7 ембріона на перенесення.

\section{Висновки}

1. Прегравідарна підготовка перед протоколом КОС $з$ поєднанням препаратів «FT 500 Plus» (інозитол, фролієва кислота, глутатіон, лютеїн, цинк, вітамін C, вітамін E, селен) та «Аквадетрим» вітамін $\mathrm{D}_{3}$ у пацієнток із безпліддям при СПкЯ покращує якість яйцеклітин, збільшує частоту настання вагітності, знижує прояви метаболічного синдрому.

2. Отримані результати свідчать, що використання короткого протоколу контрольованої стимуляції овуляції з антагоністами ГнРГ та тригером агоністом ГнРГ у пацієнток із синдромом полікістозних яєчників при безплідді є більш фрізіологічним та знижує ризик розвитку ускладнень.

Перспективи подальших досліджень. У пацієнток із синдромом полікістозних яєчників необхідно оптимізувати протоколи КОС шляхом диференційованого підходу щодо стимуляції овуляції для зменшення ризику розвитку синдрому гіперстимуляції яєчників та підвищення якості яйцеклітин, а також необхідно розробити комплексний підхід із врахуванням всіх ланок патогенезу цієї проблеми. Все це дасть змогу підвищити ефективність допоміжних репродуктивних технологій.

\section{Список літератури}

1. Гончаров Н. П. Андрогены (лекция) / Н. П. Гончаров // Проблемы эндокринологии. - 1996. - № 4. - С. $28-31$.

2. Гродницкая E. Э. Дефицит витамина D у женщин с синдромом поликистозных яичников / E. Э. Гродницкая, М. А. Курцер // Проблемы репродукции. - 2015. - № 21 (5). - С. 38-42.

3. Громова О. А. Систематический анализ молекулярно-фризиологических эфрфектов миоинозитола: данные молекулярной биологии, экспериментальной и клинической медицины / О. А. Громова, И. Ю. Торшин, О. А. Лиманова // Эфффективная фрармакотерапия в акушерстве и гинекологии. - 2013. - № 8. - С. 37-43.

4. Гуриев Т. Д. Синдром поликистозных яичников / Т. Д. Гуриев // Акушерство, гинекология и репродукция. - 2010. T. 4, № 2. - С. 10-15.

5. Назаренко Т. А. Синдром поликистозных яичников. Современные подходы к диагностике и лечению бесплодия / Т. А. Назаренко. - М. : МЕД пресс-инфрорм, 2005. - 207 с.

6. Недостатність вітаміну D в генезі порушень репродуктивного здоров'я / Т. Ф. Татарчук, О. В. Булавенко, І. М. Капшук, В. О. Тарнопольська // Український медичний часопис. - 2015. - № 5 (109). - С. 56-60.

7. Подзолкова Н. М. Современные представления о синдроме поликистозных яичников / Н. М. Подзолкова, Ю. А. Колода // Фарматека. - 2016. - № 3. - С. 8-15.

8. Про затвердження Порядку застосування допоміжних репродуктивних технологій в Україні : наказ Міністерства охорони здоров'я України від 09.09.2013 р.

9. Про удосконалення системи планування сім'ї та охорони репродуктивного здоров'я в Україні : наказ Міністерства охорони здоров'я України від 29.11.2013 р. № 1030/102.

10. Соболев Е. Л. Агонисты гонадотропин-рипизинггормона в сочетании с низкодозированными эстрогенгестагенными оральными контрацептивами в терапии СПкЯ / Е. Л. Соболев, Е. А. Златима, В. В. Потин // Акушерство и гинекология. - 2006. - № 1. - С. 25-31. 
11. Чеботникова Т. В. Синдром поликистозных яичников : учебно-методическое пособие ; под ред. И. И. Дедова / Т. В. Чеботникова, Ж. Л. Холодова. - М., 2008. - 53 с.

12. Carmina $E$. Gonadotropin-relezing-hormone agonist therapy for hirsutizmas effective a shigh do secyproterone acetate but results in a longer remission / E. Carmlna, R. A. Lobo // Ibid. - 1997. - Vol. 12, No. 4. - P. 663-666.

13. Chunla He. Serum vitamin D levels and polycystic ovary syndrome: A systematic review and meta-analysis / He. Chunla // Nutrients. - 2015. - Vol. 7 (6). - P. 4555-4577. doi: 10.3390/nu7064555

14. Correlation of ovarian stromal hypertrophy to hyperandrogenism and insulin resistance in young women with PCOS / S. Angioni // Presented at the 11-th World Congress of Gynecological Endocrinology Florence. - 2004. - Vol. 18, No. 1. P. 163-164.

15. David K. Blastocyst score affects implantation and pregnancy outcome: towards a single blastocyst transfer / K. David, D. Ph. Gardner, M. Lane [et al.] // Fertility and Sterility. - 2000. - Vol. 73, No. 6. - P. 1155-1158.

16. Garg D. InositolTreatmentand ART OutcomesinWomenwith PCOS / D. Garg, R. Tal // International Journal of Endocrinology. - 2016. Article ID1979654, 9 pages.

17. Gonadotropin-releasing hormoneagonistversus HCG foroocytetriggeringin antagonist-assisted reproductivetechnology/ Y. MAFM, F. Vander Veen, H. G. Al-Inany [et al.] // Cochrane Database of Systematic Reviews. - 2014. - No. 10. - P. 1-73. 18. Irani $M$. Role of vitamin $D$ in ovarian physiology and its implication in reproduction: a systematic review / M. Irani, Z. Merhi // Fertil. Steril. - 2014. - Vol. 102 (2). - P. 460-468.

19. Oocyte scoring enhances embryo-scoring in redicting pregnancy chances with IVF where it counts most / E. LazzaroniTealdi, D. H. Barad, D. F. Albertini [et al.] // Plos One. - 2015. - No. 2. - P. 1-13. DOI:10.1371/journal.

20. Population Reference Bureau World population data sheet of the population reference bureau: demographic data and estimates for the countries and regions of the world. Washington, DC: Population Reference Bureau; $2002 .-548 \mathrm{p}$.

21. Review and meta-analysis / Ch. Zhoumeng, H. Lin, S. Wagner Robb, A. E. Ezeamama // Nutrients. - 2015. - No. 7. P. 4555-4577. doi:10.3390/nu7064555.

22. Rienzi L. Predictive value of oocyte morphology in human IVF: a systematic review of the literature / L. Rienzi, G. Vajta, F. Ubaldi // Human Reprodn Update. - 2011. - Vol. 17, No. 1. - P. 34-45.

23. Tehrani $H$. The effect of calcium and vitamin $D$ supplementation on menstrual cycle, body mass index and hyper and rogenism state of women with polycysticovarian syndrome: a clinical trial study / H. Tehrani, F. Mostajeran, S. Shahsavari // J. Res. Med. Sci. - 2014. - No. 19. - P. 875-880.

\section{References}

1. Goncharov, N.P. (1996). Androgeny (lektsiya) [Androgens (lecture)]. Problemyendokrinologii-Problems of Endocrinology, 4, 28-31 [in Russian].

2. Grodnitskaya, Ye.E. \& Kurtser, M.A. (2015). Defitsit vitamina D u zhenshchin s sindromom polikistoznykh yaichnikov [Deficiency of Vitamin D in women with polycystic ovary syndrome]. Problemy reproduktsii - Problems of Reproduction, 21 (5), 38-42 [in Russian].

3. Gromova, O.A., Torshin, I.Yu. \& Limanova, O.A. (2013). Sistematicheskiy analiz molekulyarno-fiziologicheskikh effektov mio-inozitla - dannyye molekulyarnoy biologii, eksperementalnoy i klinicheskoy meditsiny [Systematic analysis of molecular-physiological effects of myo-inositol - dannemolecular biology, experimental and clinical medicine.]. Effektivnaya farmakoterapiya $v$ akusherstve ginekologii - Effective Pharmacotherapy in Obstetrics and Gynecology, 8, 37-43 [in Russian].

4. Guriyev, T.D. (2010). Sindrom polikistoznykh yaichnikov [Polycystic ovary syndrome]. Ausherstvo, Ginekologiya, Reproduktsiya - Akusherstvo, Gynecology, Reproduction, 4, 2, 10-15 [in Russian].

5. Nazarenko, T.A. (2005). Sindrom polikistoznykh yaichnikov. Sovremennyye podkhody k diagnostike i lecheniyu besplodiya [Syndrome of polycystic ovaries. Modern approaches to diagnosis and treatment offertility]. Moscow: MEDpress-inform [in Russian].

6. Tatarchuk, T.F., Bulavenko, O.V., Kapshuk, I.M. \& Tarnopolska, V.O. (2015). Nedostatnist vitaminu D v henezi porushen reproduktyvnoho zdorovia [Vitamin D deficiency in the genesis of reproductive health disorders]. Ukrayinskyi medychnyi chasopys - Ukrainian Medical Journal, 5 (109), 56-60 [in Ukrainian].

7. Podzolkova, N.M. \& Koloda, Yu.A. (2016). Sovremennye predstavlenyya o syndrome polykystoznykh yaichnykov [Modern presentations about the syndrome of polycystic lesions]. Farmateka - Pharmacy, 3, 8-15 [in Russian].

8. Nakaz Ministerstva okhorony zdorovia Ukrainy vid 09.09.2013r. «Pro zatverdzhennia Poriadku zastosuvannia dopomizhnykh reproduktyvnykh tekhnolohii v Ukraiini» [Order of the Ministry of Health of Ukraine dated 09.09.2013. «On Approval of the Procedure for the Application of Assisted Reproductive Technologies in Ukraine»]. [in Ukrainian].

9. Nakaz Ministerstva okhorony zdorovia Ukrainy vid 09.09.2013r. № 1030/102 «Pro udoskonalennia systemy planuvannia simi ta okhorony reproduktyvnoho zdorovia v Ukraini» [Order of the Ministry of Health of Ukraine of 11/29/2013. №1030 / 102 «On Improvement of Family Planning and Reproductive Health System in Ukraine»]. [in Ukrainian].

10. Sobolev, Ye.L., Zlatima, Ye.A. \& Potin, V.V. (2006). Agonisty gonadotropin-ripizinggormona v sochetanii s nizkodozirovannymi estrogen-gestagennymi oralnymi kontratseptivami v terapii SPKYA [Gonadotropin-Ripinghormone agonists in combination with low-dose estrogen-gestagenic oral contraceptives in therapy of PCOS]. Akusherstvo $i$ ginekologiya - Obstetrics and Gynecology, 1, 25-31 [in Russian].

11. Chebotnykova, T.V. \& Kholodova, Zh.L. (2008). Syndrom polykystoznykh yaichnikov: uchebno-metodicheskoe posobye [Polycystic ocular syndrome: educational and methodical manual]. (Ed.) I.I. Dedova. Moscow [in Russian].

12. Carmina, E. \& Lobo, R.A. (1997). Gonadotropin-relezing-hormone agonist therapy for hirsutizmas effective a shigh do secyproterone acetate but results in alonger remission. Ibid 12, 4, 663-666. 
13. Chunla, He. (2015). Serum vitamin D levels and polycystic ovary syndrome: A systematic review and meta-analysis. Nutrients, 7 (6), 4555-4577. doi: 10.3390/nu7064555

14. Angioni S. (2004). Correlation of ovarian stromal hypertrophy to hyperandrogenism and insulin resistance in young women with PCOS. Presented at the 11-th World Congress of Gynecological Endocrinology Florence, 18, 1, $163-164$.

15. David K. Gardner, D.Phil., Michelle Lane, Ph.D., John Stevens, M.T., Terry Schlenker, M.A., \& William B. Schoolcraft, M.D. (2000). Blastocyst score affects implantation and pregnancy outcome: towards a single blastocyst transfer. Fertility and Sterility, 6, (73), 1155-1158.

16. Garg, D. \& Tal R. (2016). Inositol Treatment and ART Outcomesin Womenwith PCOS. International Journal of Endocrinology, ID1979654, 9 pages.

17. MAFM, Y., Vander Veen, F., Al-Inany, H.G., Mochtar, M.H., Griesinger, G., Nagi Mohesen, M., Aboulfoutouh, I. \& van Wely, M. (2014). Gonadotropin-releasing hormoneagonistversus HCG foroocytetriggeringin antagonist-assisted reproductivetechnology. Cochrane Database of Systematic Reviews, 10, 1-73.

18. Irani, M. \& Merhi, Z. (2014). Role of vitamin D in ovarian physiology and its implication in reproduction: a systematic review. Fertil Steril., 102 (2), 460-468.

19. Lazzaroni-Tealdi, E., Barad, D.H., Albertini, D.F., Yu, Ya., Kushnir, V.A., Russell, H. ... Gleicher, N. (2015). Oocyte scoring enhances embryo-scoring in predicting pregnancy chances with IVF where it counts most. Plos One, 2, 1-13. DOI:10.1371/journal.

20. (2002). Population Reference Bureau World population data sheet of the population reference bureau: demographic data and estimates for the countries and regions of the world. Washington, DC: Population Reference Bureau.

21. Zhoumeng, Ch., Lin, H., Wagner Robb, S., \& Ezeamama, A.E. (2015). Review and Meta-Analysis. Nutrients, 7, 45554577. doi:10.3390/nu7064555.

22. Rienzi, L., Vajta, G. \& Ubaldi, F. (2011). Predictive value of oocyte morphology in human IVF: a systematic review of the literature. Human Reprodn Update, 17, 1, 34-45.

23. Tehrani, H., Mostajeran, F. \& Shahsavari, S. (2014). The effect of calcium and Vitamin D supplementation on menstrual cycle, body mass index and hyper and rogenism state of women with polycysticovarian syndrome: a clinical trial study. $J$. Res. Med. Sci., 19, 875-880.

\section{ПРЕГРАВИДАРНАЯ ПОДГОТОВКА ПАЦИЕНТОК С СИНДРОМОМ ПОЛИКИСТОЗНЫХ ЯИЧНИКОВ В ПРОГРАММАХ ЭКСТРАКОРПОРАЛЬНОГО ОПЛОДОТВОРЕНИЯ}

М.С. Хмиль

ГВУЗ «Тернопольский государственный медицинский университет имени И.Я. Горбачевского МЗ Украины»,

г. Тернополь, Украина

Цель: оценить эффективность прегравидарной терапии перед проведением контролируемой стимуляции овуляции в протоколах екстракорпорального оплодотворения у пациенток с синдромом поликистозных яичников.

Материалы и методы. Рандомизированное клинико-лабораторное исследование было проведено среди 146 женщин с верифицированным синдромом поликистозных яичников. При исследовании использованы общеклинические, эмбриологические и гормональные методы обследования, ультразвуковое исследование.

Результаты. На основе проведенных собственных исследований установлено, что у пациенток, которым применяли комплексную прегравидарную подготовку в программах вспомогательных репродуктивных технологий, наблюдались существенно более высокие показатели качества яйцеклеток, частоты дробления эмбрионов и высокий процент полученных бластоцист, также доказано, что использование криопротоколов повышает частоту начала беременности.

Выводы. Прегравидарная подготовка перед протоколом контролируемой стимуляции овуляции у пациенток с бесплодием при синдроме поликистозных яичников улучшает качество яйцеклеток, увеличивает частоту начала беременности, снижает проявления метаболического синдрома.

КЛЮЧЕВЫЕ СЛОВА: синдром поликистозных яичников; бесплодие; контролируемая стимуляция овуляции; качество яйцеклеток; FT 500 Plus; инозитол; витамин D. $_{3}$.

\section{PREGRAVIDARY PREPARATION OF PATIENTS WITH SYNDROME OF POLYCASTOSIS OVARIANS IN PROGRAMS OF EXTRACORPORAL FERTILIZATION \\ M. S. Khmil}

I. Horbachevsky Ternopil State Medical University

Purpose: evaluation of the effectiveness of polycystic ovary syndrome pre-treatment before controlled ovarian stimulation in assisted reproductive technology in patients with polycystic ovary syndrome.

Materials and Methods. A randomized controlled trial was conducted among 146 women with polycystic ovary syndrome. In the study, we used general clinical, embryological and hormonal methods of examination, ultrasound examination was also used. 
Results. Based on our own research, it was found that patients who were using complex pregravidary training in assisted reproductive technologies had significantly higher oocytes quality, frequency of embryo fragmentation and a high percentage of blastocysts obtained, and that the use of cryoprotocolol increased the incidence of pregnancy .

Conclusions. Polycystic ovary syndrome pre-treatment in vitro fertilization protocols improves the quality of oocytes, increases the pregnancy onset rates, reduces manifestations of metabolic syndrome.

KEY WORDS: polycystic ovary syndrome; infertility; controlled ovarian stimulation; oocyte quality; FT500 Plus; inositol; vitamin D3.

Рукопис надійшов до редакції 26.10.2017 p.

\section{Відомості про автора:}

Хміль Марія Стефанівна - асистент кафедри акушерства та гінекології № 1 ДВНЗ «Тернопільський державний медичний університет імені І.Я. Горбачевського МОЗ України»; тел.: +38(067) 846-35-34. 